\title{
H.C. Andersens livssyn og kristendomsforståelse
}

Opposition ex auditorio ved Kaj Mogensens Disputatsforsvar 9. maj 2018: Livet - det dejligste eventyr. H.C. Andersens teologi I-II (København: Eksistensen 2017)

\author{
Lektor em. mag.art. \\ Mogens Pahuus, Aalborg Universitet
}

\begin{abstract}
This article is not a complete assessment of Kaj Mogensen's voluminous doctoral dissertation. Instead, it focuses on two elements in Hans Christian Andersen's understanding of life and conception of Christianity: 1) God as loving providence, and 2) the importance of the freedom, endeavours and formation of the human being. It is argued that there is a range of difficulties in the first element - both in Hans Christian Andersen's thinking and in Kaj Mogensen's own corresponding approach - that are not sufficiently discussed in the dissertation. It is also argued that Mogensen to some degree underestimates the second element in Andersen's novels, poems and fairy-tales.
\end{abstract}

Keywords: God - providence - immortality - freedom - endeavours formation

\section{Indledning}

Kaj Mogensen har i sin endog meget store disputats om H.C. Andersen ikke blot forsøgt at formulere det livssyn og den kristendomsforståelse, som gennemsyrer forfatterskabet, men har gjort dette gennem en omfattende og grundig analyse af en væsentlig del af forfatterskabet, nemlig tre af de seks romaner, en lang række digte og et antal eventyr. Hertil kommer en dybtgående behandling af samtidens livsog kristendomsforståelser og en drøftelse af den meget omfattende sekundærlitteratur om emnet. Det betyder, at afhandlingen er et omfattende og rigt værk. Jeg skal i denne artikel ikke forsøge at give en egentlig vurdering af hele afhandlingen, men nøjes med at fokusere på fremstillingen af selve kernen i H.C. Andersens livs- og kristendomsforståelse. Jeg vil skelne mellem to elementer i H.C. Andersens livssyn og teologi. For det første den tanke, at Gud er et kærligt for- 
syn. For det andet dette, at et menneskes skæbne, samtidig med at denne er ledet af Gud, også bestemmes af menneskets frihed, dets stræben og dets arbejde på at udvikle sig som menneske (dannelsestanken). Kaj Mogensen er især optaget af det første element, men har efter min mening hverken i tilstrækkelig grad blik for muligheden af forskellige tolkninger af og vanskeligheder i denne tanke om Gud som det kærlige forsyn, eller haft tilstrækkelig forståelse for det andet element i H.C. Andersens livssyn og teologi.

Først skal jeg drøfte tanken om Gud som det kærlige forsyn - og flertydigheder og vanskeligheder i denne tanke. Dernæst behandles dannelsestanken - med udgangspunkt i især eventyret "Sneedronningen”. Herefter gennemgås Kaj Mogensens analyser af de tre romaner med henblik på de to elementer i H.C. Andersens livssyn og teologi. Der afsluttes dels med en kritik af Kaj Mogensens analyse af et digt, som behandler den menneskelige stræben ("Marts"), dels med en vurdering af aktualiteten i den H.C. Andersen'ske teologi, en teologi som Kaj Mogensen i vid udstrækning selv deler.

\section{Gud som det kærlige forsyn}

I H.C. Andersens selvbiografi Mit Livs Eventyr skriver han: "Mit Livs Historie vil sige Verden, hvad den siger mig: der er en kjærlig Gud, der fører alt til det Bedste”. Denne sætning resumerer det tilværelsessyn og den kristendomsopfattelse, som ifølge Kaj Mogensen er kernen i H.C. Andersens digtning, nemlig at livet for enhver er et vidunderligt eventyr. Med Kaj Mogensens ord: "Udsagnet er personligt, digterens tydning af sit eget liv, men det er også alment. Det kan opfattes som en kort sammenfatning af en teologi: "Der er en kærlig Gud der fører alt til det bedste. Gud er det kærlige forsyn” (s. 1077. Alle henvisninger er til Kaj Mogensens bog med mindre andet er anført). Verden - og ethvert menneske - er altså ifølge Kaj Mogensens tolkning af H.C. Andersen skabt af Gud, der som en fortsat skabende forsynsmagt leder ethvert menneske på dets vej gennem livet. Og eftersom der tydeligvis er ganske mange mennesker, hvis liv absolut ikke lykkes i denne jordiske tilværelse, må det forholde sig sådan, at enhver og altså ikke mindst den hårdt ramte efter døden vil leve videre og her vil få erstatning for den mislykkede jordiske tilværelse.

Tanken om Gud som forsynsmagt præger i markant grad romanen De to Baronesser, mens udødelighedstanken står centralt i romanen $A t$ vere eller ikke vere. Derfor gør Kaj Mogensen disse to romaner til de centrale analyseobjekter i sin afhandling. Foruden disse to romaner 
analyseres den sene lille roman Lykke-Peer, fordi H.C. Andersen her fremstiller sit syn på det lykkeligste jordiske liv. Desuden analyseres en lang række digte og en mindre gruppe eventyr, hvor tilværelsesforståelsen og kristendomsopfattelsen også spiller en vigtig rolle. Kaj Mogensen inddrager dog også helt bevidst tekster, der ikke forholder sig til særlige religiøse problemstillinger, og som ikke nævner Gud, men hvor han mener, "at denne gudsopfattelse og det hermed forbundne menneskesyn er en uudtalt forudsætning” (1060). Det gælder således eventyret "Svinedrengen" og i nogen grad også Lykke-Peer.

Afhandlingens tese er som sagt den, at tanken om Gud som skaber og forsynsmagt og tanken om udødeligheden er kernen i H.C. Andersens tilværelsesforståelse. Men tesen omfatter også det synspunkt, at H.C. Andersens kristendomsforståelse faktisk kan berige teologien i dag.

Kaj Mogensen har efter min mening et langt stykke ret i den første del af tesen: Gudstanken og udødelighedstanken udgør noget kernemæssigt i H.C. Andersens livssyn - og ikke mindst i de tre romaner, som analyseres. Et af mine spørgsmål i denne artikel er dog, om disse tanker er så gennemgående i forfatterskabet, som Kaj Mogensen mener. Det er fx svært at se, at de overhovedet spiller en rolle i eventyret "Svinedrengen". Men vigtigere er, at det, når det gælder testningen af denne gennemgående tese, må være oplagt at foretage en nærmere analyse af en række tekster, især en række eventyr, hvor H.C. Andersen helt åbenbart forholder sig til centrale elementer i kristendommen som bl.a. "Den lille Havfrue" og "Dyndkongens Datter". Det er en vigtig deltese hos Kaj Mogensen, at H.C. Andersens tolkning af kristendommen er i overensstemmelse med den luthersk-evangeliske forståelse af denne. Men den tese kunne man have ønsket sig afprøvet netop i forbindelse med et tankemæssigt så utraditionelt eventyr som "Dyndkongens Datter". Det er klart, at afhandlingen ikke kan inddrage alle tekster, men en række let tolkelige tekster kunne med fordel have være udeladt til fordel for andre, som mere direkte forholder sig til H.C. Andersens kristendomsforståelse.

Kaj Mogensen har fremdraget de tre romaner, hvor H.C. Andersen mest direkte fremlægger sin livsanskuelse, hvor denne altså fremtræder som et budskab og får karakter af en morale. Her er der dog grund til at indvende, at de første tre romaner (Improvisatoren, O.T. og Kun en Spillemand) er mere polyfone og i højere grad sætter modstridende livsanskuelser over for hinanden. Dertil kommer, at H.C. Andersen i de dybeste af sine eventyr får formuleret en mindre budskabspræget fremstilling af sin livsanskuelse.

På baggrund af det foretagne udvalg forekommer det ikke helt klart, hvad der ligger i tesen om Gud som det kærlige forsyn. Det er 
et spørgsmål, om ikke der for H.C. Andersen er tale om flere forskellige tanker. Tesen om det kærlige forsyn formuleres i De to Baronesser som tanken om den røde tråd, der går gennem menneskers liv. Og i denne roman fornemmer man, at den røde tråd dækker over to ting. For det første dette, at der i ethvert menneske findes en skabt kerne. "Og Kernen er god, den holder sig fra vor Herre. Skallen har Verden givet Kulør" (med den gamle baronesses ord). Derfor er alle mennesker ligeværdige, sådan som det også udtrykkes af den gamle baronesse: "Vi er alle eet Stykke". Den anden tanke er den, at Gud som forsynsmagt er med til at sørge for, at vi udvikler os gennem prøvelser. For Elisabeth er dette faktisk kernen i forsynstroen. Det fremgår af følgende citat:

Hun husker Moritz Ord om den røde Traad. - Hun saae den i de Aar, hun havde levet, hun saae hvor nødvendig, hvor velsignelsesrig, hver tung Omskiftelsesdag havde været hende; hun forstod, at i det eensomme Liv på Oland, mellem Natur og Bibel, var en rigere Sæd nedlagt i hendes Sjæl, end der i den velhavende Gaard hos den gamle underlige Baronesse vilde have været Mulighed for. ${ }^{1}$

Tilsvarende hedder det om Herman:

Der laa ni Aar imellem, ni Aar, tilbragt i fremmede Lande, hvor Naturen, Kunsten og Verdenslivet havde været hans Opdragere, og det må indrømmes, at i hvor højt man end sætter Skolelærdom og al Kundskab tilegnet ved Flid og Besvær, så giver dog Livet selv noget mere; i dette var han ikke omdannet, men udviklet, havde vundet Klarhed med sig selv og Verden. ${ }^{2}$

Man kan også tolke tanken om forsynsmagten og den røde tråd på den måde, at Gud ved et menneskes fødsel har bestemt, hvordan dette menneskes liv skal forme sig. Det forekommer dog at være en meget mere problematisk tænkemåde. Men det kunne se ud, som om det er på denne måde, Kaj Mogensen tolker forsynstanken - fx der hvor han lægger op til, at det ved Elisabeths fødsel er blevet bestemt af Gud, at hun skulle giftes med Herman (133). Det gør en stor forskel, om man opfatter tesen om det kærlige forsyn på den måde, at det svære og lidelsesfulde kan gives mening som noget, der udvikler og modner en - eller om man forstår den som et udsagn om, at Gud er styrende og bestemmende med i alt, hvad der sker. Da vil der jo

1. H. C. Andersen, Romaner og Rejseskildringer, udg. af M. Borup (København Gyldendal 1943) Bd. IV, s. 275-76.

2. ibid. s. 229. 
i virkeligheden aldrig være noget som helst, som blot er tilfældigt, og derfor ej heller ulykker, der rammer helt tilfældigt. Vi kommer tilbage til spørgsmålet.

På tilsvarende måde kan udødelighedstanken forstås på noget forskellig måde. For det første på den måde, at eftersom der er mennesker, der lider umenneskeligt, kan vi tro og håbe på, at der en tilværelse efter denne, hvor ofrene oprejses. Sådan kunne man tolke udødelighedstanken for grumslingens vedkommende (i At vare eller ikke vare). Det forekommer, at det i denne bog anfægter H.C. Andersen, at der findes mennesker, som slet ikke når at udvikle en egentlig menneskelighed. Men når det gælder Niels Bryde selv, da dækker udødelighedstanken over noget andet og noget mere selvisk, nemlig dette at man ikke klarer at forlige sig med tanken om, at man selv tilintetgøres ved døden. Begge elementer findes hos H.C. Andersen, men det forekommer, at Kaj Mogensen ikke har så megen sans for det første element $\mathrm{i}$ udødelighedstanken.

Det er helt utvivlsomt, at H.C. Andersen livet igennem anfægtes i denne sin livsforståelse (at livet er det dejligste eventyr - for enhver). Disse anfægtelser kommer først og fremmest til orde $\mathrm{i}$ andre romaner (og andre tekster) end dem, der analyseres i afhandlingen, og derfor må man sige, at man $\mathrm{i}$ afhandlingen ikke får et fuldstændigt billede af H.C. Andersens forhold til kristendommen. Hertil kommer, at den gennemgående fokusering på forsyns- og udødelighedstanken kommer til at skygge for andre centrale elementer i H.C. Andersens livsforståelse, især hans menneskesyn med de forskellige højere og lavere lag i mennesket, som spiller en afgørende rolle i nogle af hans dybeste eventyr ("Den lille Havfrue" og "Dyndkongens Datter"), og hans syn på den menneskelige dannelses- eller udviklingsproces, som findes $\mathrm{i}$ mange romaner og eventyr. Kaj Mogensen nævner selv dannelsestanken mange steder, men udfolder den ikke rigtigt og synes også at have en noget kontroversiel opfattelse af den. I alle fald benægter han, at der er tale om udvikling hos Elisabeth (i De to Baronesser) og hos Gerda (i "Sneedronningen"), hvor mange andre fortolkere opfatter skildringen af disse to personer som i udpræget grad bestemt af dannelsestanken forstået som en udvikling fra umiddelbarhed over refleksion og (selv) beherskelse til en genvundet umiddelbarhed. På samme måde undrer det, når Kaj Mogensen i sin analyse af At vare eller ikke vare skriver om denne, at den er "ingen rigtig dannelsesroman, for det højdepunkt som Niels Bryde er ledt frem til, er hans barndom” (387), for dannelsestanken går jo netop ud på, at det barnlige tilbageerobres og altså er med i modenheden, blot på et højere niveau. 


\section{Dannelsestanken}

Ifølge H.C. Andersen er det afgørende for et menneske at kunne erkende den usynlige tråd $\mathrm{i}$ et liv, og det er endvidere afgørende at bevare kernen i sig selv, noget som tydeligt ses i barnets umiddelbarhed, dets tillid og tro, som det gerne skulle fastholde. Det er det, som Gerda har i "Sneedronningen" - jf. hvad finnekonen siger om hende:

Seer Du ikke, hvor Mennesker og Dyr må tjene hende, hvorledes hun på bare Been er kommet saa vel frem i Verden. Hun maa ikke af os vide sin Magt, den sidder i hendes Hjerte, den sidder i, hun er et sødt, uskyldigt Barn." 3

Men samtidig ses livet som en udvikling gennem prøvelser. Der skal mere til end umiddelbarheden.

Jeg mener, at Kaj Mogensen i sin tolkning ikke yder denne tanke om udvikling, om menneskelig dannelse, tilstrækkelig retfærdighed. Det er, som om Kaj Mogensen holder sig til det skabte - det gudgivne. Det præger især hans tolkning af "Sneedronningen".

Kaj Mogensen når frem til den overraskende konklusion, at der i dette eventyr ikke er tale om en udviklings- eller dannelsestanke. Hverken Gerda eller Kaj udvikler sig. "Gerda ændrer sig ikke" (981). "Myten er ikke en sammentrængt dannelsesroman" (1014). Når man betænker, at de to tredjedele af eventyret (3.-7. billede) handler om Gerdas søgen efter Kaj, og når man videre med Kaj Mogensen må sige, at hun her på denne mangeslyngede rejse møder både mange farer for og fristelser til at glemme Kaj (1019), er det overraskende, når Kaj Mogensen mener, at alt dette ikke rummer en udvikling af Gerda. Lad os se nærmere på det første billede, hvor Gerda opholdes af besøget hos den gamle kone, som ikke er en rigtig heks, men som tydeligvis med sin have og alle dens blomster forsinker Gerda og et vist stykke får hende til at glemme Kaj. Hvad er der tale om her? En nærliggende tolkning er, at Gerda gennemgår en fase, hvor kærlighedslængsel og kærlighedsdrømme dominerer, og hvor hun derfor ikke er i så direkte kontakt med virkeligheden, men hvor hun så at sige fristes af de mange forskellige aspekter af kærligheden til at "glemme" det centrale i hendes egen kærlighed til Kaj, nemlig dette at være optaget af den anden og dennes ve og vel på en selvforglemmende måde. Det er det, rosen står for. Og alle de andre blomster, vi hører om, står for andre elementer i kærligheden, som nok kan føre

3. H. C. Andersen: Samlede Eventyr og Historier (København Gyldendal 1962), Bd. I. s. 295. 
på afveje: Ildliljen (og den hertil knyttede fortælling) står for den lidenskabelige, brændende kærlighed; convolvolussen står for den anelsesfulde, forventningsfulde kærlighedslængsel; sommergækken (som vi kalder vintergækken) står for den gækkende, flygtige og ustadige betagelse eller forelskelse; hyacinthen for den farlige kærlighed, der kan ende med døden; smørblomsten står for den ikke-erotiske kærlighed; og endelig står pinseliljen eller narcissen for den selvkærlige og selvoptagne form for kærlighed.

Det skal i øvrigt bemærkes, at Kaj Mogensen misforstår den lille fortælling, der knytter sig til ildliljen, når han skriver, at "enken elskede sin mand og fulgte ham ind i døden”. Nej, enken tænker - da hun står på bålet - på en anden, som endnu lever. Hun repræsenterer altså en utro kærlighed:

I sin lange røde Kjortel staa Hindu-Konen på Baalet, Flammerne slaae op om hende og hendes døde Mand; men Hindu-Konen tænker på den levende her i Kredsen, ham hvis Øine brænder hedere end Flammerne, han, hvis Øines Ild naae mere hendes Hjerte, end de Flammer, som snart brænde hendes Legeme til Aske. Kan Hjertets Flammer døe i Baalets Flammer? ${ }^{3}$

På tilsvarende måde er der tale om, at Gerda lærer noget i mødet med den frejdige prins (i hvert fald styrkes den frejdighed og frimodighed, som hun allerede er i besiddelse af), ligesom hun lærer noget om magt og vold (og det vigtige $\mathrm{i}$ at undgå sådanne midler) i mødet med røverdatteren, ligesom det ikke kan være tilfældigt, at både lappekonen og finnekonen står for det erkendelsesmæssige, som Gerda naturligvis også må udvikle, selv om det er rigtigt, at det allervæsentligste er en selvforglemmende umiddelbarhed, som hun har med sig hele vejen igennem. Kaj Mogensen nøjes med at betone dette sidste.

Man kan i øvrigt tænke om de næste tre historier i eventyret ("Prinds og Prinsesse", "Den lille Røverpige" og "Lappekonen og Finnekonen") som beretninger om mødet med tre verdener. Først den fornemme verden med dens kunstlethed og unatur, som prinsen rebellerer imod. Dernæst den fattige eller proletariske verden, som man så den, da den gjorde oprør i 1830 i Frankrig (sml. "Drengen på Frankrigs Trone" i Billedbog uden billeder). Og endelig er den tredje verden den lærde verden.

Det må være meget mere nærliggende at tænke om hele Gerdas rejse som et udviklingsforløb end som en pendant til Jesu liv, inkarnation, passion og opstandelse (1018-20).

4. ibid. s. 280 . 
Og også Kaj udvikler sig dog - modsat Kaj Mogensen: "Kaj udvikler sig ikke i fortælllingen" (1019). Han gennemløber de klassiske tre stadier i dannelsestænkningens opstilling af forløbet: fra umiddelbarhed over refleksion og beherskelse til genvundet (og af mellemfasen beriget) umiddelbarhed.

\section{Romanerne}

Det afgørende i Kaj Mogensens afhandling er som sagt analyserne af de tre romaner, som udgør godt og vel halvdelen af afhandlingen.

\section{De to Baronesser}

For en nutidig læser af denne roman er det nærliggende at anke over, at den opererer med lovlig mange heldige sammentræf. I og med at vi af en fortælling (roman eller drama) forventer, at den skal kunne kaste lys over den menneskelige tilværelse, skal den rumme et sandsynligt handlingsforløb. Og her kan man synes, at det er temmelig usandsynligt, at Elisabeth fødes og bliver gift i det selvsamme hus, samtidig med at hun ved fødslen hjælpes af den person, hun senere bliver gift med - kombineret med at de to lever hele den mellemliggende tid helt forskellige steder i verden, og at det er en kæde af tilfældigheder, der fører dem sammen igen efter de mange år. Men hvis man forestiller sig, at der findes et guddommeligt forsyn, der ved Elisabeths fødsel har bestemt, at hun skulle giftes med Herman (og sådan tolker Kaj Mogensen romanen, s. 95 pff), da kan man ikke længere tale om usandsynlige sammentræf. Som Kaj Mogensen skriver: "forfatteren kan jo ikke gøre for, at Gud har spundet en usynlig tråd i både menneskets levnedsløb og romanens fortælleforløb". Men dette er jo at ophæve enhver tanke om tilfældigheder, og da kan man ikke længere tale om det usandsynlige, og spørgsmålet er da, om en livsforståelse, der ikke anerkender tilfældigheder og sandsynlighed, er en plausibel livsforståelse.

Kaj Mogensen har bestemt forståelse for, at når især Elisabeth skal gennemgå mange genvordigheder, skyldes det, at hun skal udvikles og modnes, men alligevel mener jeg - som det også fremgik af kritikken af analysen af "Sneedronningen" - , at Kaj Mogensen er tilbøjelig til at undervurdere det formende og dannende i den udviklingsproces, mennesker gennemgår. Han skriver om Elisabeth, at hendes udvikling og modning ikke består i andet end "en indsigt i og forståelse af den røde tråd, der har løbet igennem hendes liv" (142). Personlig- 
hedsdannelse omfatter meget andet end forståelse og indsigt - også ifølge H.C. Andersen.

Den gamle baronesse skal i sagens natur ikke gennemgå en egentlig udvikling på samme måde som de to unge - Elisabeth og Herman. Hun skal ifølge Kaj Mogensen nå frem til "forsoning med sit liv" (161). Det mener jeg er rigtigt, men jeg mener ikke, det er rigtigt med Kaj Mogensen at forstå denne forsoning med sit liv som det, at hun skal erkende sin skyld i forbindelse med, at hendes datter blev voldtaget af en italiensk røver (og det er Herman, der er frugten af denne voldtægt). "Hun ville ikke se sin skyld i øjnene" (121). Når hun blev skyld i (forstået som medvirkende årsag til) at hendes datter blev voldtaget, var det jo alene, fordi hun var utålmodig efter at komme frem til rejsens mål og derfor satte igennem, at man forlod landevejen og tog turen over bjerget, og noget sådant er jo ikke en moralsk skyld. $\mathrm{Og}$ kun i forbindelse med en sådan giver det mening at tale om at se den i øjnene og tage den på sig. Det, som hun skal forsone sig med, er simpelthen, at der er noget illegitimt og socialt vanærende $\mathrm{i}$ hendes liv.

Også Moritz må gennemgå det lidelsesfulde. I hans tilfælde handler det om, at hans elskede Caroline dør få dage før deres bryllup. På sin vis kan man forstå Moritz, når han - i sin første prædiken for menigheden på Halligerne (som Kaj Mogensen i parentes bemærket konsekvent kalder for Hallingerne) - siger, at "Gud har prøvet mig tungt, taget fra mig hvad jeg hældede mit Hoved og mit Hjerte til for at jeg skulde holde mig fastere til ham, for at jeg i min Sorg skulle forstaae andres. Som til Job kommer Sorgen og Ulykken til os, at vi kunne forstå Gud, os selv, hin og denne Verden!” (67). Man kan givetvis med sin holdning give mening til ulykken. Men det er problematisk at mene (hvad både H.C. Andersen og Kaj Mogensen gør), at Gud har den mening at modne Moritz, når han lader Caroline dø. Det vil jo være at bruge et menneske blot som redskab. Nøjagtig det samme må man sige om Niels Brydes elskede Esthers død i At vare eller ikke vare. Kaj Mogensen skriver her, at hun dør, "for at Niels kan få øje på det evige liv" (272). Vi er nu engang ikke i tvivl om, at det for os mennesker er paradigmet på at handle umoralsk at bruge et andet menneske kun som middel (jf. Kants anden formulering af det kategoriske imperativ). Så må det også være det for Gud. Og her hjælper det ikke at sige, at "Esthers jordiske død betinger både hendes egen og Niels Brydes evige lykke". For på denne måde bliver udødelighedstanken en retfærdiggørelse af absolut alt. 


\section{At vare eller ikke vare}

Der er i denne roman en anden parallel til De to Baronesser. Ligesom den gamle baronesse ifølge Kaj Mogensen pådrog sig skyld i forbindelse med datterens voldtægt, således pådrager Karen sig skyld i forbindelse med grumslingens og dennes mors skæbne. Men også hun er dog i moralsk henseende aldeles uskyldig. Uanset hvordan H.C. Andersen har tænkt om denne skyld, kan man i dag ikke tale om moralsk skyld her.

Kaj Mogensen kan have ret i, at H.C. Andersen bevidst ikke fremstillede de stærkeste repræsentanter for kristendomskritikken (som bl.a. Feuerbach), men at han angreb datidens populær-materialisme. Men ifølge Kaj Mogensen skyldes det ikke, at han gjorde sig opgaven lettere, men at han forholdt sig til det i tiden, der fyldte mest for de fleste. Men når man som Kaj Mogensen vil hævde, at H.C. Andersens livsforståelse kan inspirere kristendommen i dag, må det siges at være uheldigt at knytte til ved kritikken af den vulgære materialisme. Når Kaj Mogensen på egne vegne skal beskrive alternativer til troen på Gud, tenderer han også til en vulgær-opfattelse, fx når han på s. 354 skriver, at alternativet er enten fortvivlelse eller det at ophøje mennesket til Gud (som i socialdarwinismen og i guddommeliggørelsen af staten).

Kaj Mogensen viser, at H.C. Andersen på god protestantisk vis skelner mellem det, der er op til mennesket, og det centrale i troen, som er Guds gave til mennesket, som mennesket altså ikke når frem til gennem egen indsats - samtidig med at der kan være andre elementer $\mathrm{i}$ troen, som er tilkæmpede. Men må man ikke sige, at H.C. Andersen har en noget problematisk og indskrænket opfattelse af tro, når han lader den af Gud skænkede tro primært være en tro på udødelighed (som om udødelighedstanken skulle være kernen i den kristne tro)? Tanken om et evigt liv, hvor man samtidig har bevidsthed om eller husker, hvem man var i det jordiske liv, forekommer at være en noget selvisk tanke, hvor det grundlæggende i kristendommen dog må have med selvforglemmelse at gøre, ikke mindst i forhold til andre.

Når det gælder H.C. Andersens trosbegreb, bedyrer Kaj Mogensen, at "enhver form for overtro er afmonteret" (329). Det er dog svært at se, at der ikke er overtro på spil i forbindelse med klaverstrengens bristen efter Esthers død. For det første siger H.C. Andersen selv, at Niels "blev i dette nu Overtroens Barn". For det andet forekommer det ikke, at det her giver mening at tale om "et åbent virkelighedsbegreb" og om en foregribelse af den post-positivisme, nogle gør gældende i dag, og om et slægtsskab med Dorthe Jørgensens tanker om poesi/æstetik som en selvstændig type erkendelse (hvilket Kaj Mogensen gør, bl.a. s. 398). 
I forbindelse med analysen af Lykke-Peer siger Kaj Mogensen igen, at ravhjertet ikke har med overtro at gøre. Igen er det svært at se argumentet.

\section{Lykke-Peer}

Kaj Mogensen fremhæver, at det jordiske liv har selvstændig værdi for H.C. Andersen (en tænkemåde han er helt enig i). Men han diskuterer slet ikke, om H.C. Andersen med alderen bliver mere skeptisk over for det dennesidige. Man kunne dog godt tolke den centrale tanke i denne lille sene roman (at det lykkeligste er at dø som ganske ung, hvor man er på sit højdepunkt) som en mistillid til det jordiske og kødelige livs naturlige stadier. Det er jo, som om Lykke-Per skal dø ung for at undgå de skuffelser og de nederlag og de svagheder, som er en naturlig del af ethvert livsløb.

Det forekommer, at Kaj Mogensen tolker romanen (som for ham er mere et eventyr end en roman) som mindre almengyldig end de andre romaner. At det er en roman kun om en udvalgt, en person som har et ganske bestemt livsmål. Det passer nu ikke alt for godt med H.C. Andersens erklærede holdning, at alle mennesker er lige.

Men uanset hvor udvalgt Lykke-Per er, kunne man godt lidt mere problematisere tanken om, at et livsmål er et ganske bestemt resultat, som man på et tidspunkt når frem til. Thorvaldsen (som Lykke-Per helt til slut sammenlignes med i romanen) havde vel et livsmål - et kald - men det bestod ikke i et enkelt værk, men i et helt livs arbejde med at skabe og udvikle skaberevnen. Spørgsmålet er, om man ikke forråder livet ved at gøre det til redskab for et bestemt værk. Man kunne også problematisere ideen om, at man kulminerer i sit liv eller er på sit højdepunkt, der hvor andre erkender ens storhed - altså har succes. Når Lykke-Per af H.C. Andersen selv sammenlignes med Thorvaldsen, ville H.C. Andersen's tankegang indebære, at Thorvaldsen ville have været lykkeligere, hvis han var død efter skabelsen af sit første storværk "Jason med det gyldne skind". Og det forekommer dog ikke ret plausibelt.

Spørgsmålet er så, om Lykke-Per skal forstås ikke bare som den udvalgte, men mere præcist som den udvalgte kunstner? Kaj Mogensen mener nemlig, at "kunstneren må dø for at hans kunst kan leve". Det er svært at se, hvorfor Kaj Mogensen skulle have ret i dette: Kunstværket er jo i sin virkning helt uafhængigt af skaberen af det. Men når Kaj Mogensen tænker således, må det vel hænge sammen med, at han er af den opfattelse, at der i Lykke-Pers tilfælde er tale om en pendant til Jesus. Det forekommer lige så lidt overbevisende, som at Gerda i "Sneedronningen" er det. 
Nogle af de tidligere berørte problemer dukker op igen i forbindelse med denne roman. Der er for det første tale om den frie viljes problem: Det forekommer ikke at være tilstrækkeligt at sige, som Kaj Mogensen gør, at Lykke-Pers frihed består i at "give sig hen til det han er bestemt for" (552). For det andet er der spørgsmålet om, hvorvidt Lykke-Per gennemgår en udvikling. Kaj Mogensen mener, at Lykke-Per ikke udvikler sig (563), men blot ledes frem til at erkende, hvad der er hans livs bestemmelse. Det forekommer tvivlsomt. Han udvikler sig i høj grad gennem modgang og prøvelser. Akkurat ligesom Aladdin, som romanen explicit henviser til. Men her gælder det, at Kaj Mogensen (og måske også H.C. Andersen) undervurderer, i hvilken udstrækning Oehlenschlägers Aladdin er en dannelsesroman (sml. 561-64). Måske er det her symptomatisk, at selv om det meget tydeligt af romanen fremgår, at Lykke-Peer er stærkt inspireret af Aladdin, så nævnes Oehlenschlägers navn slet ikke i Kaj Mogensens bog. Der er altså næppe tale om, at Kaj Mogensen har gennemført et egentligt studium af Oehlenschlägers værk. Oehlenschlägers navn nævnes heller ikke i Lykke-Peer, men ingen er dog i tvivl om, at H.C. Andersen har studeret det skuespil grundigt.

\section{Frihed og stræben}

Noget andet, som bliver underbelyst i afhandlingen, er den vægt, som H.C. Andersen lægger på den menneskelige stræben. Det er rigtigt, at H.C. Andersen (som betonet af Kaj Mogensen) har forståelse for, at der er et element i troen, som ikke kan vindes gennem stræben og indsats, men som er en gave fra Gud (og denne evangelisk-lutherske tanke kommer tydeligt frem i At vare eller ikke vare), men Kaj Mogensen underbetoner, at H.C. Andersen lige så markant betoner elementet af menneskelig stræben i troen. Det er jo det, der gør Goethes Faust så vigtig for Esther (i At vare eller ikke vare) - og det er også det, der giver Prometheus en central position i bl.a. digtet "Marts", som analyseres grundigt $\mathrm{i}$ afhandlingen (771-803). Jeg vil dog mene, at netop betydningen af det stræbende i dette digt ikke er forstået ret. H.C. Andersen skriver i digtet "Marts":

Om Laplands Bjerge snor sig Sumpelandet,

Men frodigt gror de røde Bær paa Vandet;

Tilintetgørelsen sit Banner svinger,

Men engang ogsaa Tiden her den tvinger.

Urskovens Dynd med Sumpene forgaae, 
Og Byer der i Dalene skal staae,

Hvor Karavaner smægtede i Sandet,

Skal Mennesket fremtrylle: Kanaans-Landet! ${ }^{5}$

Her skriver Kaj Mogensen, at den evige bevægelse og kamp mellem liv og død ikke betyder, at det ikke vil ende harmonisk, for det er ånden, der vil sejre over formens død. "Kampen vil ende med de gode kræfters sejr." (776). Der står imidlertid ikke noget om, at kampen vil ende eller ophøre. Og slet ikke, at den vil ophøre med harmoniens sejr. Selv om der henvises til Kanaans land, så er dette ikke et synonym for Paradiset, men et stadium i den evige kamp.

Men vigtigere er, at H.C. Andersen umiddelbart efter det forrige citat skriver:

For den vilde Syndflods Vande,

Svinder Bjerge, Byer, Lande,

Men ei Snillet den betvinger -

Frelste Slægter Arken bringer;

Høit på Ararat de dale;

Jorden snart er blomster-Sale.

- Lænket fast til Døgnets Klipper

Ei Prometheus Faklen slipper. ${ }^{6}$

Kaj Mogensen skriver her, at "syndfloden kan ikke betvinges af menneskets snilde" (777). Men det er forkert. Der står jo, at snildet betvinger syndflodens vande. (Man kan ganske vist læse sætningen således, at snildet ikke betvinger syndfloden, men i så fald bortfalder den modsætning, der markeres med ordet "men", og en sådan læsning vil også være uforenelig med den efterfølgende sætning om, at arken bringer frelste slægter, og arken er jo blevet bygget af mennesker - og derfor er det altså - også - i kraft af menneskers snilde, at syndfloden blev overvundet).

I begge citater tænker H.C. Andersen mere i pagt med Goetheske figurer som Faust og Prometheus (jf. digtet af Goethe) og mindre evangelisk-luthersk, end Kaj Mogensen så at sige på forhånd går ud fra.

5. http://andersen.sdu.dk/vaerk/digte/vis.html?vid=1766.

6. ibid. 


\section{Aktualiteten i H.C. Andersens teologi}

Hvad angår den anden del af Kaj Mogensens tese - at H.C. Andersens kristendomsforståelse med forsynstanken og udødelighedstanken i centrum udgør en aktuel inspirationskilde for teologien i dag - gælder det, at Kaj Mogensens argumentation herfor ikke er ret udførligt udarbejdet.

Man må her for det første gøre sig klart, at H.C. Andersens kristendomsforståelse er tæt forbundet med romantikkens metafysiske tænkemåde, og selv om Kaj Mogensen henviser til, at metafysikken er genoptaget hos aktuelle teologer som Løgstrup og nogle af hans elever og af en idehistoriker som Dorthe Jørgensen, er det alligevel ganske anderledes former for metafysik end romantikkens. Hertil kommer, at både Løgstrup og Jørgensen først og fremmest henviser til en række erfaringer, som lægger en metafysisk og religiøs tolkning nær (med et løgstrupsk udtryk). Men den oven for nævnte radikale forsynstanke og udødelighedstanke, som Kaj Mogensen gør gældende, må da vist siges at være helt og aldeles erfaringsresistent. Uanset hvad der sker - uanset hvilke meningsløse og katastrofale ulykker mennesker rammes af - kan man hævde, at der er en dybere mening, som så først vil vise sig i evigheden. Samtidig fremgår det imidlertid, at Kaj Mogensen selv mener, at man kan sætte forsynstanken på prøve, og at det er det, H.C. Andersen gør i sine romaner - $\mathrm{fx}$ med beretningen om grumslingen i At vare eller ikke vare. Men man kan dog ikke sige, at hverken H.C. Andersen eller Kaj Mogensen i dette tilfælde viser eller godtgør, at "selv i det mest forkrøblede menneskeliv ligger spiren til det fuldkomne liv" (333). På tilsvarende måde må det siges at være et rent postulat - noget der på ingen måde godtgøres i denne afhandling - når Kaj Mogensen for egen regning hævder følgende: "At Gud findes og at mennesket er udødeligt er mere sandsynligt end det modsatte" (398). Der henvises her hverken til erfaringer eller til mere fornuftsmæssige ræsonnementer.

Nok må man sige, at H.C. Andersen ræsonnerer angående udødelighed i At vare eller ikke vare, men spørgsmålet er, hvor mange filosoffer og teologer der er, som i dag vil finde disse ræsonnementer overbevisende.

En helt central indvending mod den forsynstanke, som fremføres af Kaj Mogensen, er, at denne tanke er vanskelig at forene med tanken om mennesket som et selvbestemmende, frithandlende væsen. Det kræver i alle fald en udførlig argumentation, hvis man skal kunne hævde begge synspunkter. Men her nøjes Kaj Mogensen med at postulere, at "forsyn og frihed udelukker ikke hinanden" (141). Der gives ingen argumentation. Og det bliver ikke mere indlysende, at der 
er tale om ægte selvbestemmelse, når Kaj Mogensen om Elisabeth skriver, at "Elisabets frihed består i, at hun følger den usynlige tråd".

\section{Afslutning}

Noget centralt i den evangelisk-lutherske kristendomsforståelse er udsagnet om retfærdiggørelse ved tro alene. Denne tanke spiller også en central rolle for H.C. Andersen. Jeg er også selv helt overbevist om, at der i et menneske og et menneskeliv er noget, som ikke er den enkeltes egen indsats og fortjeneste, og at vi alle beror på, at vort liv lykkes i kraft af noget i livet, som er større end os, livet selv eller livets kilde. Men jeg er lige så sikker på, at dette må sammentænkes med noget, der er lige så indlysende, nemlig frihed, stræben og dannelse/udvikling. Sådan tænkte - efter min mening - H.C. Andersen, og jeg mener, at denne tanke har gyldighed også i dag. Men denne anden tanke mener jeg ikke er tilstrækkelig betonet i Kaj Mogensens afhandling.

Ligesom Kaj Mogensens tese er todelt i den forstand, at den både angår tolkningen af nogle af de centrale livsanskuelsesmæssige grundtanker i H.C. Andersens forfatterskab, og at den argumenterer for, at H.C. Andersens kristendomsforståelse kan berige teologien i dag, således har jeg i denne artikel forsøgt at påvise, både at der er elementer i H.C. Andersens livsanskuelse, sådan som den foreligger i det digteriske forfatterskab, som Kaj Mogensen ikke i tilstrækkelig grad har forstået og inddraget, og at pege på nogle af de vanskeligheder, som knytter sig til den opfattelse af kristendommen, som H.C. Andersen gør sig til talsmand for, og som Kaj Mogensen også tilslutter sig. 